JURNAL IPA TERPADU

p-ISSN : 2597-8977

e-ISSN : 2597-8985

http://ojs.unm.ac.id/index.php/ipaterpadu

\section{PENERAPAN VIDEO TUTORIAL BERBASIS E-LEARNING UNTUK MENINGKATKAN KETUNTASAN BELAJAR PESERTA DIDIK REMEDIAL KELAS VIII SMPN 18 MAKASSAR \\ (STUDI PADA MATERI POKOK USAHA DAN PESAWAT SEDERHANA)}

Teguh Putra Gusal *) Universitas Negeri Makassar

Ramlawati Universitas Negeri Makassar

Muhammad Aqil Rusli Universitas Negeri Makassar
*) Correspondence Author: Teguh.pugu@gmail.com
Abstrak: Penelitian ini adalah penelitian pre-eksperimen yang bertujuan untuk mengetahui (1) Tingkat hasil belajar peserta didik remedial setelah menggunakan video tutorial berbasis e-learning, (2) Peningkatan hasil belajar peserta didik remedial setelah menggunakan video tutorial berbasis e-learning, dan (3) Persentase ketuntasan belajar peserta didik remedial setelah menggunakan video tutorial berbasis e-learning. Sampel penelitian adalah peserta didik remedial yang telah mengikuti daring sebanyak 71 peserta didik. Pengambilan sampel disebut purposive sampling. Instrumen dalam penelitian tes hasil belajar terdiri dari pretest dan posttest yang berupa pilihan ganda sebanyak 20 butir. Data ketuntasan belajar peserta didik diperoleh dari hasil test ulangan harian dan tes akhir atau posttest. Teknik analisis data yaitu dengan analisis statistik deskriptif kuantitatif. Hal ini dapat disimpulkan bahwa pencapaian ketuntasan belajar peserta didik remedial kelas VIII.9, VIII.10 dan VIII.11 SMPN 18 Makassar setelah melalui bimbingan remedial menggunakan video tutorial berbasis e-learning adalah sebesar 35,21\%.

Kata Kunci: Video Tutorial, E-learning, Remedial, Hasil Belajar

Abstract: This research is a pre-experimental research, which aims to know (1) The level of learning outcomes of remedial students after using video tutorials based on e-learning, (2) Improving learning outcomes of remedial students after using video tutorials based on e-learning, and (3) Percentage of mastery learning remedial students after using video tutorials based on e-learning. The sample of research was remedial students who have taken online was 71. Sampling is called purposive sampling. The instrument in this study was pretest and posttest learning outcomes test which is in the form of multiple choice as many as 20 items. Student's completeness learning data obtained from the results of pretest and posttest. The data analysis technique is quantitative descriptive statistical analysis. It can be concluded that the achievement of mastery learning in remedial students in class VIII.9, VIII.10 and VIII.11 SMPN 18 Makassar after going through remedial guidance using video tutorials based on e-learning is $35,21 \%$.

Keyword: Video tutorials, E-Learning, Remedial, Learning Outcomes 


\section{PENDAHULUAN}

Perkembangan teknologi informasi dan komunikasi yang sangat pesat mempengaruhi dunia pendidikan. Kemajuan teknologi informasi dan komunikasi membuat proses belajar mengajar ter digitalisasi. Digitalisasi tersebut seperti kelas online, pengumpulan tugas online dan lain sebagainya. Era digital telah memperkenalkan dunia pendidikan dengan e-learning system yaitu suatu sistem atau konsep pendidikan yang memanfaatkan Teknologi Informasi dan Komunikasi (TIK) dalam proses belajar mengajar. Perubahan-perubahan dalam dunia pendidikan di era digital ini diharapkan dapat membuat proses pembelajaran lebih efektif dan efisien.

Dalam proses belajar mengajar (PBM) masih terdapat masalah yang dihadapi oleh guru yakni terkait ketuntasan belajar. Ketuntasan belajar ditentukan oleh kemampuan penguasaan peserta didik terhadap sejumlah kompetensi yang dipelajari. Berdasarkan hasil observasi peneliti di SMPN 18 Makassar, masih terdapat permasalahan yang dialami oleh guru terkait ketuntasan belajar ini. Masih banyak peserta didik yang nilainya tidak mencapai Kriteria Ketuntasan Minimal (KKM). Kebanyakan nilai peserta didik yang tidak mencapai KKM ada pada mata pelajaran IPA yang lebih menekankan banyak perhitungan. Nilai KKM yang diterapkan pada kelas VIII SMPN 18 Makassar yaitu 80. Oleh karena itu, peserta didik yang tidak mencapai nilai 80 maka harus menjalani bimbingan remedial.

Pengertian KKM dalam Peraturan Menteri Pendidikan Nasional Republik Indonesia No.20 tahun 2007 tertanggal 11 Juni 2007 tentang standar penilaian pendidikan adalah singkatan dari Kriteria Ketuntasan Minimal. KKM adalah Kriteria Ketuntasan Belajar (KKB) yang ditentukan oleh satuan pendidikan (Gustia \& Susanti, 2018). Menurut Siregar dan Hatika (2019) Kriteria Ketuntasan Minimal (KKM) adalah kriteria ketuntasan belajar yang ditentukan oleh satuan pendidikan yang mengacu pada standar kompetensi kelulusan dengan mempertimbangkan karakteristik peserta didik, karakteristik muatan pelajaran, dan kondisi satuan pendidikan. Penentuan KKM harus mempertimbangkan setidaknya 3 aspek, yakni karakteristik peserta didik (intake), karakteristik muatan/ mata pelajaran (kompleksitas), dan kondisi satuan Pendidikan (pendidik dan daya dukung).

Hasil belajar merupakan prestasi peserta didik secara keseluruhan, yang menjadi indikator kompetensi dasar dan derajat perubahan perilaku yang bersangkutan. Faktor-faktor yang mempengaruhi proses dan hasil belajar dapat digolongkan menjadi empat yaitu (a) bahan atau materi yang dipelajari; (b) lingkungan; (c) faktor instrumental; (d) kondisi peserta didik. Faktorfaktor tersebut baik secara terpisah maupun bersama-sama memberikan kontribusi tertentu terhadap hasil belajar peserta didik (Mulyasa, Iskandar, \& Aryani, 2016).

Menurut Hartini (2013) bagi peserta didik yang dengan pencapaian kompetensi belum mencapai Kriteria Ketuntasan Minimal (KKM), maka peserta didik tersebut akan mendapat bimbingan remedial untuk memperbaiki kemampuan yang dimiliki yang didahului dengan analisis kesulitan atau kelemahannya dan diakhiri dengan penilaian kemajuan belajarnya (Prasetyo, Supraptono, \& Utami, 2016). Menurut wawancara, bimbingan remedial hanya dilakukan maksimal dua kali oleh guru di SMP Negeri 18 Makassar. Ketika nilai peserta didik masih belum mencapai KKM maka akan diberikan pengulangan soal dengan tingkat kesulitan yang lebih rendah atau pengumpulan tugas yang relevan. Namun muncul masalah baru ketika peserta didik yang remedial diberikan tes dengan tingkat kesulitan yang lebih rendah, yaitu apakah dengan tes yang diberikan dapat mencapai kompetensi yang ada. Selain itu, masalah yang muncul dalam pelaksanaan remedial juga dihadapi oleh guru, yaitu dengan adanya bimbingan remedial itu berarti tambahan pekerjaan dan menyita banyak waktu bagi seorang guru. Karena hal tersebut guru terpaksa memberikan bimbingan remedial kepada peserta didik di sela jam pembelajaran yang seharusnya dilakukan di luar pembelajaran. Ketika hal ini dilakukan maka masalah lain muncul yakni jumlah jam pada mata pelajaran akan berkurang karena adanya bimbingan remedial dan tentunya akan mengakibatkan terlambatnya pembahasan topik yang sedang dipelajari. 
E-learning merupakan tools dalam pembelajaran dan pelatihan yang memanfaatkan koneksi internet dan berinteraksi berbasis website. Penggunaan e-learning tidak terbatas pada jarak, ruang dan waktu. Hal tersebut membuat para user dapat menggunakannya dimana pun dan kapan pun. Guru dapat menyampaikan materi secara online, sehingga KBM dapat berjalan dengan lancar walaupun guru tersebut tidak berada di kelas. Selain itu proses ujian dapat dilakukan menggunakan internet, dengan kata lain peserta didik tidak perlu mendatangi lokasi ujian dan membutuhkan banyak kertas dalam pencetak soal ujian (Abdulmajid, Pramuntadi, Riyanto, \& Rochmah, 2017).

Dengan demikian, diadakan penelitian untuk mengetahui (1) Tingkat hasil belajar peserta didik remedial setelah menggunakan video tutorial berbasis e-learning, (2) Peningkatan hasil belajar peserta didik remedial setelah menggunakan video tutorial berbasis e-learning, dan (3) Persentase ketuntasan belajar peserta didik remedial setelah menggunakan video tutorial berbasis e-learning.

\section{METODE}

Jenis penelitian yang digunakan dalam penelitian ini adalah penelitian eksperimen. Desain penelitian yang digunakan dalam penelitian ini termasuk pre-experimental design. Desain penelitian yang digunakan adalah dengan menggunakan One-Group Pretest-Posttest. Penelitian ini dilaksanakan pada semester ganjil tahun ajaran 2018-2019 di SMP Negeri 18 Makassar.

Pengambilan sampel yaitu dengan menggunakan Purposive Sampling, merupakan pengambilan sampel secara sengaja sesuai dengan karakteristik, sifat-sifat dari suatu populasi (Kurniawan, 2018). Adapun sampel yang digunakan dalam penelitian ini adalah peserta didik remedial yang telah mengikuti daring sebanyak 71 orang yang berasal dari populasi yang memuat seluruh peserta didik kelas VIII.9, VIII.10 dan VIII.11 SMP Negeri 18 Makassar pada tahun ajaran 2018/2019 yang nilainya tidak mencapai Kriteria Ketuntasan Minimum (KKM) sebanyak 90 peserta didik.

Teknik pengumpulan data dilakukan dengan cara memberikan tes yang terdiri dari pretest (tes awal) dan posstest (tes akhir) pada peserta didik remedial. Tes tersebut adalah soal pilihan ganda yang berjumlah 20 butir soal. Data yang diperoleh dari hasil penelitian ini berupa data kuantitatif yang selanjutnya dianalisis dengan menggunakan teknik analisis deskriptif. Analisis dengan menggunakan statistik deskriptif dilakukan untuk memberikan gambaran atau mendeskripsikan data yang telah terkumpul, dalam hal ini berupa hasil belajar yang dicapai oleh peserta didik baik setelah menjalani bimbingan remedial.

\section{HASIL DAN PEMBAHASAN}

1. Hasil

\section{a. Deskripsi Data Hasil Belajar Peserta Didik Remedial}

Deskripsi data hasil belajar peserta didik memperlihatkan data hasil belajar peserta didik yang telah dianalisis menggunakan analisis statistik deskriptif. Data hasil belajar peserta didik dapat dilihat pada tabel berikut. 
Tabel 1. Deskripsi Skor Hasil Belajar Peserta Didik

\begin{tabular}{cccc}
\hline \multirow{2}{*}{ No } & Statistik & \multicolumn{2}{c}{ Sampel } \\
\cline { 3 - 4 } & Jumlah Sampel & Pretest & Posttest \\
\hline 1 & Skor Tertinggi & 71 & 71 \\
2 & Skor Terendah & 15 & 20 \\
3 & Skor Rata-rata & 4 & 8 \\
4 & Standar Deviasi & 9,93 & 13,39 \\
5 & Varians & 2,81 & 3,47 \\
6 & & 7,92 & 12,01 \\
\hline
\end{tabular}

Berdasarkan tabel diperoleh bahwa skor hasil tes hasil belajar pada materi usaha dan pesawat sederhana yang terdiri dari 71 peserta didik menunjukkan hasil skor pretest dengan skor tertinggi yang dicapai oleh peserta didik adalah 15, sedangkan skor terendah adalah 4 dengan rerata skor 9,93. Kemudian diperoleh standar deviasi 2,81 dan varians 7,92. Adapun skor hasil belajar IPA peserta didik pada posttest menunjukkan skor tertinggi yang dicapai adalah 20, sedangkan skor terendah adalah 8 dengan skor rerata 13,39. Kemudian diperoleh standar deviasi 3,47 dan varians data 12,01.

\section{b. Hasil Analisis Tingkat Hasil Belajar Peserta Didik Remedial}

Hasil analisis tingkat hasil belajar peserta didik remedial memperlihatkan sebaran data hasil belajar peserta didik remedial yang digolongkan kedalam 4 predikat yaitu A (sangat baik), B (baik), C (cukup) dan D (kurang). Tingkat hasil belajar peserta didik remedial dapat dilihat pada tabel berikut.

Tabel 2. Predikat Tingkat Hasil Belajar Peserta Didik Remedial setelah Menggunakan Video Tutorial Berbasis E-Learning

\begin{tabular}{cccc}
\hline Interval Predikat & Frekuensi & Persentase (\%) & Predikat \\
\hline $93<A \leq 100$ & 7 & 9,86 & Sangat Baik \\
$86<B \leq 93$ & 2 & 2,82 & Baik \\
$80 \leq C \leq 86$ & 16 & 22,54 & Cukup \\
$D<80$ & 46 & 64,79 & Kurang \\
\hline
\end{tabular}

Berdasarkan tabel di atas, menunjukkan hasil pengategorian hasil belajar peserta didik remedial kelas VIII (VIII.9, VIII.10, dan VIII.11) SMP Negeri 18 Makassar setelah menggunakan video tutorial berbasis e-learning. Jumlah peserta didik remedial setelah menjalani bimbingan remedial menggunakan video tutorial berbasis e-learning dengan tingkat hasil belajar pada kategori sangat baik adalah 7 orang dengan persentase 9,86\%. Kemudian jumlah peserta didik pada kategori baik adalah 2 orang dengan persentase 2,82\%. Jumlah peserta didik pada kategori cukup adalah 16 orang dengan persentase $22,54 \%$. Jumlah peserta didik pada kategori kurang adalah 46 orang dengan persentase $64,79 \%$. Rerata nilai peserta didik setelah menggunakan video tutorial berbasis e-learning adalah 66,97 tergolong dalam predikat $\mathrm{D}$ (Kurang).

\section{c. Hasil Analisis Statistik Deskriptif Untuk N-Gain}

Hasil analisis gain ter-normalisasi ( $\mathrm{N}$-gain) memperlihatkan peningkatan hasil belajar peserta didik remedial dan digolongkan kedalam 3 kategori yaitu tinggi, sedang dan rendah. Peningkatan hasil belajar peserta didik remedial dapat dilihat pada tabel berikut. 
Tabel 3. Deskripsi Kategori N-gain Hasil Belajar Peserta Didik Remedial

\begin{tabular}{|c|c|c|c|}
\hline Indeks Gain & Kriteria & Frekuensi & Persentase (\%) \\
\hline$g \geq 0,70$ & Tinggi & 10 & 14,08 \\
\hline $0,70>g>0,30$ & Sedang & 29 & 40,85 \\
\hline $0,30 \geq \mathrm{g}$ & Rendah & 32 & 45,07 \\
\hline \multicolumn{2}{|c|}{ Jumlah } & 71 & 100 \\
\hline
\end{tabular}

Berdasarkan tabel di atas, setelah menjalani bimbingan remedial menggunakan video tutorial berbasis e-learning, sebanyak 10 peserta didik memiliki hasil $\mathrm{N}$-gain dengan kategori tinggi yaitu sebesar $14,08 \% 29$ peserta didik dengan kategori sedang sebesar 40,85\% serta terdapat 32 peserta didik dengan kategori rendah yaitu sebesar $45,07 \%$.

\section{d. Pencapaian Setiap Indikator Peserta Didik Remedial}

Deskripsi pencapaian setiap indikator peserta didik remedial memperlihatkan peningkatan jumlah peserta didik yang tuntas pada setiap indikator pada pretest dan posttest. Persentase peserta didik remedial yang tuntas pada setiap indikator dapat dilihat pada tabel berikut.

Tabel 4. Persentase Ketuntasan Setiap Indikator

\begin{tabular}{|c|c|c|c|c|}
\hline \multirow{2}{*}{ No } & \multirow{2}{*}{ Indikator } & \multirow{2}{*}{ Jumlah Soal } & \multicolumn{2}{|c|}{ Jumlah Peserta Didik (\%) } \\
\hline & & & Pretest & Posttest \\
\hline 1 & Menuliskan Konsep Usaha & 3 & 52,11 & 67,61 \\
\hline 2 & $\begin{array}{l}\text { Memberi contoh usaha dalam kehidupan sehari- } \\
\text { hari }\end{array}$ & 3 & 64,79 & 81,69 \\
\hline 3 & $\begin{array}{l}\text { Menghitung besar usaha dan jarak benda yang } \\
\text { dikenai usaha }\end{array}$ & 3 & 47,89 & 66,20 \\
\hline 4 & Mengidentifikasi jenis-jenis pesawat sederhana & 5 & 46,48 & 73,24 \\
\hline 5 & $\begin{array}{l}\text { Menghitung keuntungan mekanik pesawat } \\
\text { sederhana }\end{array}$ & 3 & 46,48 & 63,38 \\
\hline 6 & $\begin{array}{l}\text { Menjelaskan penerapan prinsip kerja pesawat } \\
\text { sederhana pada sistem gerak }\end{array}$ & 3 & 36,62 & 80,28 \\
\hline
\end{tabular}

Berdasarkan Tabel 4 terdapat 6 indikator dengan jumlah soal proporsional pada setiap indikator. Hasil pretest menunjukkan persentase peserta didik yang tuntas pada indikator 1 adalah $52,11 \%$, indikator 2 sebesar $64,79 \%$, indikator 3 sebesar $47,89 \%$, indikator 4 sebesar $46,48 \%$, indikator 5 sebesar $46,48 \%$ dan indikator 6 sebesar 36,62\%. Sedangkan, setelah melalui bimbingan remedial dengan menggunakan video tutorial berbasis e-learning menunjukkan peningkatan persentase peserta didik yang tuntas pada setiap indikator yaitu pada indikator 1 meningkat menjadi $67,61 \%$, indikator 2 meningkat menjadi $81,69 \%$, indikator 3 meningkat menjadi $66,20 \%$, indikator 4 meningkat menjadi 73,24\%, indikator 5 meningkat menjadi 63,38\% dan indikator 6 meningkat menjadi 80,28\%

Peningkatan jumlah peserta didik remedial yang tuntas pada setiap indikator dapat dilihat pada diagram berikut. 


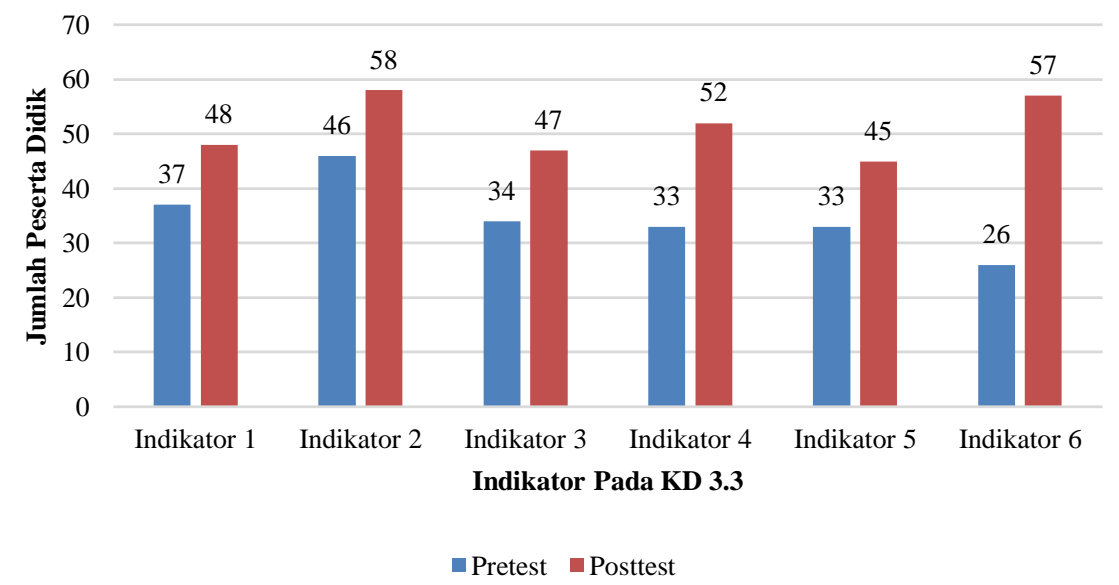

\section{Gambar 1. Diagram Pencapaian Tiap Indikator Peserta Didik Remedial}

Berdasarkan gambar menunjukkan jumlah peserta didik yang tuntas saat pretest pada indikator 1 adalah 37 orang, indikator 2 berjumlah 46 orang, indikator 3 berjumlah 34 orang, indikator 4 berjumlah 33 orang, indikator 5 berjumlah 33 orang dan indikator 6 berjumlah 26 orang. Sedangkan, setelah melalui bimbingan remedial dengan metode pemberian video tutorial berbasis e-learning menunjukkan peningkatan jumlah peserta didik yang tuntas pada setiap indikator yaitu pada indikator 1 meningkat menjadi 48 peserta didik, indikator 2 meningkat menjadi 58 peserta didik, indikator 3 meningkat menjadi 47 peserta didik, indikator 4 meningkat menjadi 52 peserta didik, indikator 5 meningkat menjadi 45 peserta didik dan indikator 6 meningkat menjadi 57 peserta didik.

\section{e. Persentase Ketuntasan Belajar Peserta Didik}

Persentase ketuntasan belajar peserta didik memperlihatkan seberapa besar persentase peserta didik dengan skor mencapai ketuntasan belajar setelah mengikuti bimbingan remedial menggunakan video tutorial berbasis e-learning. Ketuntasan peserta didik remedial kelas VIII.9, VIII.10 dan VIII.11 SMP Negeri 18 Makassar dapat dilihat pada tabel berikut.

Tabel 5. Deskripsi Ketuntasan Peserta Didik Remedial

\begin{tabular}{cccccc}
\hline No & Deskripsi & Skor Ketuntasan & Jumlah & Rata-rata Skor & Persentase(\%) \\
\hline 1 & Tuntas & \multirow{2}{*}{16} & 25 & 17,32 & 35,21 \\
2 & Tidak Tuntas & & 46 & 11,26 & 64,79 \\
\hline
\end{tabular}

Tabel di atas menunjukkan bahwa setelah menjalani bimbingan remedial menggunakan video tutorial berbasis e-learning jumlah peserta didik yang tuntas adalah 25 orang dengan ratarata skor 17,32 dan memiliki persentase ketuntasan 35,821\% dari total keseluruhan peserta didik remedial. Sedangkan peserta didik yang tidak tuntas adalah sebanyak 46 orang dengan rata-rata skor 11,26 dan memiliki persentase $64,79 \%$.

\section{Pembahasan}

Penelitian yang telah dilakukan dengan menggunakan video tutorial berbasis e-learning $\urcorner$ pada kelas VIII SMPN 18 Makassar dimulai dengan pengambilan data peserta didik yang nilainya tidak mencapai Kriteria Ketuntasan Minimal (KKM) pada ulangan harian materi usaha dan pesawat sederhana dengan jumlah soal pilihan ganda sebanyak 20 butir soal. KKM yang diterapkan SMPN 18 Makassar khususnya dalam mata pelajaran IPA adalah 80. Didapatkan jumlah 
peserta didik yang tidak mencapai KKM yaitu sebanyak 90 orang. Kemudian sampel penelitian diambil dengan metode purposive sampling yaitu sampel adalah peserta didik remedial yang telah mengikuti daring sebanyak 71 peserta didik. Jumlah peserta didik dengan nilai tidak mencapai ketuntasan minimal (KKM) terbilang sangat tinggi. Jumlah peserta didik kelas VIII.9, VIII.10 dan VIII.11 SMPN 18 Makassar yaitu 100 orang dan peserta didik yang remedial sebanyak 90 orang. Dengan kata lain hanya 10\% peserta didik yang nilainya mencapai KKM pada materi pokok usaha dan pesawat sederhana. Menurut Saharuddin \& Wahab (2019) bahwa materi pelajaran yang susah lulus KKM adalah beberapa materi yang ada hubungannya dengan fisika. Jadi menurut peneliti banyaknya peserta didik yang remedial dikarenakan materi usaha dan pesawat sederhana adalah materi yang didalamnya terdapat perhitungan. Video tutorial berbasis e-learning dapat ditonton secara berulang dan dapat diputar kapan saja, sehingga mata pelajaran mayoritas perhitungan dapat dipelajari secara maksimal.

Berdasarkan data tes awal peserta didik yang diperoleh, skor rata-rata peserta didik masih rendah yaitu 9,93. Angka ini terbilang rendah karena angka tersebut masih sangat jauh dibawah skor maksimal yaitu 20. Setelah pengumpulan data dari hasil tes awal, peserta didik kemudian diberikan perlakuan dengan diberikan video tutorial sebanyak 12 video pada grup WhatsApp yang telah dibuat sebelumnya. Pemberian video tutorial dilakukan secara berkala dan pada waktu yang tak tentu dikarenakan prinsip dasar dari pembelajaran e-learning adalah dapat dilakukan dimana pun dan kapan pun. Hal ini sejalan dengan Pujiriyanto dalam Simanihuruk, et al (2019) mengemukakan bahwa pembelajaran dengan sistem e-learning mempunyai tingkat efektivitas relatif sama dengan pembelajaran konvensional namun dari sisi fleksibilitas e-learning jauh lebih unggul daripada pembelajaran konvensional karena e-learning sangat mungkin untuk diakses secara mandiri dimana pun dan kapan pun, peserta didik dapat berinteraksi dengan guru dan peserta didik lain. Kemudian dengan adanya media video maka peserta didik akan lebih tertarik dalam mempelajari materi serta mereka dapat mengulang bagian materi mana yang belum mereka mengerti. Sejalan dengan Saenab, Ramlawati, \& Suryani (2018) bahwa penggunaan video lebih efektif dalam meningkatkan hasil belajar peserta didik, artinya peserta didik yang belajar dengan menggunakan media video memiliki kemampuan yang lebih tinggi dibandingkan dengan tanpa penggunaan media video.

Setelah pembagian video tutorial pada grup WhatsApp telah selesai, kegiatan berikutnya ialah dengan pemberian posttest yang bertujuan untuk mengetahui pemahaman konsep peserta didik remedial pada aspek kognitif pada materi usaha dan pesawat sederhana. Pemberian tes akhir dilakukan di Laboratorium Komputer SMPN 18 Makassar dengan menggunakan sistem Local Area Network (LAN). Sejalan dengan Pratiwi dalam Hasanah, Suyanto, \& Suana (2016) yang mengatakan bahwa satu hal yang perlu ditekankan dan dipahami adalah bahwa e-learning tidak dapat sepenuhnya menggantikan kegiatan pembelajaran konvensional di kelas. E-learning dapat menjadi partner atau saling melengkapi dengan pembelajaran konvensional di kelas. E-learning bahkan menjadi komplemen besar terhadap model pembelajaran di kelas atau sebagai alat yang ampuh untuk program pengayaan.

Hasil tes akhir peserta didik yang diperoleh menunjukkan perbedaan pada skor rata-rata yang mengalami peningkatan dari tes awal 9,93 menjadi 13,39 pada tes akhir. Peneliti melihat bahwa peningkatan skor hasil belajar peserta didik remedial dikarenakan pemberian video dilakukan secara online dan tersimpan di grup WhatsApp sehingga peserta didik dapat melihat dan mempelajari video tutorial tersebut kapan pun dan dimana pun serta dapat dilihat secara berulang dan berkelanjutan. Sejalan dengan yang disampaikan oleh Syahmaidi \& Hidayat (2016) Pembelajaran dengan menggunakan media e-learning berbasis video dapat membuat peserta didik meningkatkan aktivitas, membantu kemandirian belajar dan dapat membantu menumbuhkan pengalaman belajar peserta didik dalam setiap kegiatan pembelajaran.

Trianto dalam Magfirah, Mamin, \& Mun'im (2018) menyatakan bahwa salah satu masalah pokok dalam pembelajaran pada pendidikan formal (sekolah) dewasa ini adalah masih rendahnya 
daya serap peserta didik. Pada pembelajaran suasana kelas cenderung teacher-center. Dalam arti yang lebih substansial, bahwa proses pembelajaran hingga dewasa ini masih memberikan dominasi guru dan tidak memberikan akses bagi anak didik untuk berkembang secara mandiri melalui penemuan dan proses berpikirnya. Olehnya itu dalam penelitian ini diterapkan video tutorial berbasis e-learning agar peserta didik secara mandiri dapat aktif untuk belajar. Setelah penerapan video tutorial berbasis e-learning pada peserta didik remedial kelas VIII.9, VIII.10 dan VIII.11 SMPN 18 Makassar, perolehan skor tes akhir bervariasi. Tingkat hasil belajar peserta didik remedial setelah menjalani bimbingan remedial dapat dikategorikan yang mendapat skor dengan kategori sangat baik terdapat 7 orang dengan persentase sebesar 9,86\%. Kemudian jumlah peserta didik remedial yang mendapat skor dengan kategori baik terdapat 2 orang dengan persentase 2,82\%. Peserta didik remedial dengan skor dalam kategori cukup sebanyak 16 orang dengan persentase 22,54\%. Kemudian peserta didik dengan skor pada kategori kurang adalah 46 orang dengan persentase $64,79 \%$. Berdasarkan pengategorian tingkat hasil belajar, peserta didik dengan nilai $\geq$ KKM yakni dari rentang predikat C (cukup), B (baik) dan predikat A (sangat baik). Dengan kata lain peserta didik dengan predikat $\mathrm{D}$ (kurang) adalah peserta didik yang tidak tuntas atau memerlukan pengayaan.

Media video merupakan media alternatif yang dapat membantu peserta didik dalam memahami suatu konsep karena dapat dilihat secara berulang. Setelah menjalani bimbingan remedial menggunakan media video tutorial berbasis e-learning hasil belajar peserta didik mengalami peningkatan. Terdapat 10 peserta didik memiliki skor $\mathrm{N}$-gain dengan kategori tinggi yaitu sebesar 14,08 persen, 29 peserta didik dengan kategori rendah sebesar 40,85 persen serta terdapat 32 peserta didik dengan kategori rendah yaitu sebesar 45,07 persen. Peningkatan hasil belajar peserta didik memiliki rata-rata skor $\mathrm{N}$-gain 0,33 tergolong dalam kategori sedang. Hal ini menunjukkan video tutorial berbasis e-learning dapat mengikatkan hasil belajar peserta didik remedial. Sejalan dengan Teng dalam Syaidah, Suana, \& Sesunan (2018) bahwa video tutorial mendukung efektivitas kemandirian peserta didik, kinerja tugas dan pembelajaran. Chandra \& Nugroho (2017) juga menyatakan bahwa media video merupakan media audio-visual yang dapat membuat peserta didik tertarik serta dapat diputar ulang sehingga bagi peserta didik dengan daya tangkap kurang dapat mempelajari ulang materi sampai mengerti. Terdapat 9 peserta didik yang memiliki skor $\mathrm{N}$-gain minus. Hal tersebut dikarenakan jumlah skor tes awal lebih banyak dibandingkan tes akhir. Peneliti melihat bahwa hal tersebut dapat terjadi karena ada faktor individu yakni peserta didik terkait tidak menonton semua video tutorial yang dibagikan. Hal tersebut terlihat dari angket video tutorial yang dibagikan.

Berdasarkan data hasil belajar peserta didik pada tes awal dan tes akhir, jumlah peserta didik yang lulus pada setiap indikator meningkat. Jumlah indikator dari KD 3.3 (Menjelaskan konsep usaha, pesawat sederhana, dan penerapannya dalam kehidupan sehari-hari termasuk kerja otot pada struktur rangka manusia) pada tes awal dan tes akhir adalah sama, sebanyak 6 indikator yaitu: (1) Menuliskan Konsep Usaha, (2) Memberi contoh usaha dalam kehidupan seharihari, (3) Menghitung besar usaha dan jarak benda yang dikenai usaha, (4) Mengidentifikasi jenisjenis pesawat sederhana, (5) Menghitung keuntungan mekanik pesawat sederhana, dan (6) Menjelaskan penerapan prinsip kerja pesawat sederhana pada sistem gerak.

Hasil pretest menunjukkan persentase peserta didik yang tuntas pada indikator 1 adalah $52,11 \%$ dan mengalami peningkatan pada hasil posttest menjadi $67,61 \%$. Persentase peserta didik yang tuntas pada indikator 2 sebesar $64,79 \%$ pada pretest dan mengalami peningkatan pada posttest menjadi $81,69 \%$. Persentase peserta didik yang tuntas pada indikator 3 sebesar $47,89 \%$ pada pretest dan mengalami peningkatan pada posttest menjadi $66,20 \%$. Persentase peserta didik yang tuntas pada indikator 4 sebesar $46,48 \%$ pada pretest dan mengalami peningkatan pada posttest menjadi $73,24 \%$. Persentase peserta didik yang tuntas pada indikator 5 sebesar $46,48 \%$ pada pretest dan mengalami peningkatan pada posttest menjadi $63,38 \%$. Persentase peserta didik yang tuntas pada indikator 6 sebesar $36,62 \%$. pada pretest dan mengalami peningkatan pada 
posttest menjadi $80,28 \%$. Berdasarkan data yang diperoleh, video tutorial berbasis e-learning dapat meningkatkan hasil belajar peserta didik. Hal ini sejalan dengan Mayer dalam Khairani, Sutisna, \& Suyanto (2019) yang mengatakan bahwa dibanding dengan media gambar, penggunaan media video pembelajaran lebih meningkatkan hasil belajar peserta didik. Sehingga dengan adanya media video pembelajaran membuat peserta didik lebih termotivasi dalam belajar yang pada akhirnya meningkatnya hasil belajar peserta didik.

Jumlah peserta didik remedial yang pencapaian indikatornya dinyatakan tuntas adalah sebanyak 25 orang dengan rata-rata skor 17,32 dan memiliki persentase ketuntasan sebesar $35,21 \%$. Sedangkan peserta didik remedial yang tidak tuntas sebanyak 46 orang dengan skor ratarata 11,26 dan memiliki persentase ketuntasan sebesar $64,79 \%$. Ketuntasan belajar peserta didik remedial setelah mengikuti bimbingan remedial dengan metode pemberian video tutorial berbasis e-learning yaitu sebesar 35,21\%. Menurut peneliti penyebab rendahnya persentase ketuntasan belajar peserta didik dikarenakan faktor individual seperti tidak melihat semua video tutorial yang dibagikan dan atau tidak mempelajari secara keseluruhan isi dari video tutorial dikarenakan kontrol dari pendidik hanya sebatas di media sosial karena berbasis online dan tidak ada tatap muka secara langsung antara pendidik dan peserta didik seperti bimbingan remedial konvensional. Sejalan dengan Yazdi (2012) bahwa e-learning memiliki keruangan seperti kurangnya interaksi antar guru dan peserta didik atau bahkan antar peserta didik itu sendiri serta peserta didik yang tidak memiliki motivasi belajar tinggi cenderung gagal. Persentase ketuntasan belajar peserta didik dapat dilihat pada diagram berikut:

Seperti yang dikatakan Pujiriyanto dalam Simanihuruk, et al (2019) bahwa penerapan elearning dalam pembelajaran sekolah direkomendasikan untuk diterapkan namun perlu dilakukan kontrol terhadap penggunaanya baik kontrol pada peserta didik maupun kontrol pada guru sekolah itu sendiri. Faktor negatif pada e-learning juga tidak dapat dihindari, namun kemunculan faktor negatif tersebut sebenarnya berasal dari diri pribadi peserta didik dan guru itu sendiri. Penerimaan terhadap berkembangnya teknologi dalam pembelajaran sekolah dan kesiapan alat serta kemampuan menggunakan teknologi juga harus diperhatikan. Penyebab peserta didik remedial tidak menonton dan mempelajari video tutorial yang dibagikan adalah karena tidak mempunyai kuota atau data internet sehingga peserta didik tidak dapat online. Seperti yang dikatakan Darmayanti, Setiani, \& Oetojo (2007) cepatnya perkembangan teknologi informasi dan komunikasi (Information and Communication Technology/ICT) memungkinkan adanya penggunaan media elektronik seperti komputer dalam menyebarkan informasi. ICT dalam bidang Pendidikan memicu berkembangnya e-learning. E-learning atau electronic learning adalah sebuah konsep dalam proses pembelajaran dengan menggunakan ICT, khususnya menggunakan media yang berbasis Internet.

\section{KESIMPULAN}

Berdasarkan penelitian yang telah dilakukan tentang penerapan video tutorial berbasis $e$ learning pada ketuntasan hasil belajar peserta didik remedial kelas VIII SMPN 18 Makassar dapat disimpulkan bahwa pencapaian ketuntasan belajar peserta didik remedial kelas VIII SMP Negeri 18 Makassar setelah melalui bimbingan remedial menggunakan video tutorial berbasis e-learning adalah sebesar $35,21 \%$. 


\section{DAFTAR PUSTAKA}

Abdulmajid, N. W., Pramuntadi, A., Riyanto, A. B., \& Rochmah, E. (2017). Penerapan E-learning Sebagai Pendukung Adaptive Learning Dan Peningkatan Kompetensi Siswa Smk Di Kabupaten Bantul. Jurnal Taman Vokasi, 5(2), 171-172.

Chandra, F. H., \& Nugroho, Y. W. (2017). Implementasi Flipped Classroom Dengan Video Tutorial Pada Pembelajaran Fotografi Komersial. Jurnal Desain Komunikasi Visual, Manajemen Desain Dan Periklanan, 2(1), 23.

Darmayanti, T., Setiani, M. Y., \& Oetojo, B. (2007). E-learning Pada Pendidikan Jarak Jauh: Konsep Yang Mengubah E-learning Pada Pendidikan Jarak Jauh: Konsep Yang Mengubah. Jurnal Pendidikan Terbuka Dan Jarak Jauh, 8(2), 101.

Hasanah, N., Suyanto, E., \& Suana, W. (2016). E-learning Dengan Schoology Sebagai Suplemen Pembelajaran Fisika Materi Elastisitas Dan Hukum Hooke. Jurnal Pembelajaran Fisika, 4(2), 72.

Kurniawan , A. (2018). Metodologi Penelitian Pendidikan. Bandung: PT Remaja Rosdakarya.

Magfirah, A., Mamin, R., \& Mun'im, A. (2018). Pengaruh Media Gambar Pada Model Pembelajaran Langsung Terhadap Hasil Belajar Peserta Didik Kelas VIII MTS Muhammadiyah Cabang Mamajang (Studi Pada Materi Pokok Sistem Pencernaan). Jurnal IPA Terpadu (JIT), 2(1), 8.

Mulyasa, Iskandar, D., \& Aryani, W. D. (2016). Revolusi Dan Inovasi Pembelajaran (Sesuai Standar Proses). Bandung: PT Remaja Rosdakarya.

Prasetyo, E. (2015). Rancang Bangun Sistem Informasi Sekolah Tinggi Ilmu Ekonomi Rahmanyah Kabupaten Musi Banyuasin Berbasis Website. Jurnal Informanika, 1(2), 20.

Saenab, S., Ramlawati, \& Suryani, I. (2018). Pengaruh Media Video Dengan Pendekatan Kontektual Terhadap Hasil Belajar IPA Kelas VII MTS Negeri Gantarang Kab. Bantaeng (Pada Materi Pokok Pencemaran Lingkungan). Jurnal IPA Terpadu (JIT), 1(2), 64.

Saharuddin, \& Wahab, M. (2019). Analisis Kesulitan Dalam Pemebelajaran IPA Di Smp Negeri Limboro. Jurnal IPA Terpadu (JIT), 2(2), 79-80.

Sherlyanita, K. A., \& Rakhmawati, A. N. (2016). Pengaruh Dan Pola Aktivitas Penggunaan Internet Serta Media Sosial Pada Siswa SMPN 52 Surabaya. Journal Of Information Systems Engineering And Business Intelligence, 2(1), 18.

Simanihuruk, L., Simarmata, J., Sudirman, A., Hasibuan, M. S., Safitri, M., Sulaiman, O. K., ... Sahir, S. H. (2019). E-learning: Implementasi,Strategi Dan Inovasinya. Medan: Yayasan Kita Menulis.

Sugiyono. (2017). Metode Penelitian Pendidikan. Bandung: Alfabeta.

Syahmaidi, E., \& Hidayat, H. (2016). Studi Perancangan E-learning Dengan Open Source Moodle Di SMA Sungai Penuh, Jambi. Jurnal Nasional Pendidikan Teknik Informatika (Janapati), 5(2), 93.

Syaidah, N., Suana, W., \& Sesunan, F. (2018). Development Of Tutorial Video For Higher Order Thinking Practice On The Topic Of Newton's Law. Kasuari: Physics Education Journal (Kpej), 1(2), 92.

Yazdi, M. (2012). E-learning Sebagai Media Pembelajaran Interaktif Berbasis Teknologi Informasi. Jurnal Foristek, 2(1), 147-148. 


\section{Teguh Putra Gusal}

Mahasiswa Program Studi Pendidikan IPA FMIPA UNM, aktif melakukan penelitian pada bidang Pendidikan IPA, dapat dihubungi melalui email: teguh.pugu@gmail.com

\section{Ramlawati}

Dosen Program Studi Pendidikan IPA FMIPA UNM, aktif melakukan penelitian pada bidang Pendidikan IPA, dapat dihubungi melalui email: ramlawati@unm.ac.id

\section{Muhammad Aqil Rusli}

Dosen Program Studi Pendidikan IPA FMIPA UNM, aktif melakukan penelitian pada bidang Pendidikan IPA, dapat dihubungi melalui email:m.aqilrusli@gmail.com 